\title{
Cherry Tomato Supplementation Reduces Cardiovascular Risk
}

\author{
Jong-Ho Koh ${ }^{1}$, Young-Hee Lim $^{2}$ and Dahyun Hwang ${ }^{3,4, \uparrow}$ \\ ${ }^{1}$ Department of Bio-Food Analysis, Bio-campus, Korea Polytechnics College, Chungnam 32943, Korea \\ ${ }^{2}$ Department of Public Health Science (BK21 PLUS Program), Graduate School, \\ Korea University, Seoul 02841, Korea \\ ${ }^{3}$ Department of Biomedical Laboratory Science, College of Life and Health Sciences, \\ Hoseo University, Chungnam 31499, Korea \\ ${ }^{4}$ The Research Institute for Basic Sciences, Hoseo University, Chungnam 31499, Korea
}

\begin{abstract}
Tomatoes are rich in nutrients and have many beneficial advantages on human health. Four cherry tomato supplementation diets (CTSDs) were prepared from the juice and cake of fresh and processed (heat-treated) cherry tomatoes. Rats were fed CTSDs for 28 days and the changes in health indices in the serum were analyzed. CTSDs significantly decreased $(P<0.05)$ food efficiency ratio compared with the control. CTSD feeding significantly increased $(P<0.05)$ the high-density lipoprotein cholesterol level compared with the control, which resulted in a significant $(P<$ 0.05 ) decrease in coronary artery risk index and atherogenic index. Furthermore, CTSD feeding increased serum serotonin level. These results indicate that CTSD shows antihyperlipidemic effect.
\end{abstract}

Key Words: Cherry tomato, Atherogenic index, Coronary artery risk index, Serotonin

\section{INTRODUCTION}

The atherogenic index (AI) and the coronary artery risk index (CRI) are reliable indicators of the risk of cardiovascular diseases. An increase in the blood lipid level leads to hyperlipidemia which is the leading cause of cardiovascular disease and death worldwide. Increasing the high-density lipoprotein cholesterol (HDL-C) lowers the risk of cardiovascular diseases by reversing cholesterol transport, inhibiting low-density lipoprotein cholesterol (LDL-C) oxidation, and platelet aggregation (Barter, 2005; Berrougui et al., 2012). Food is an important factor to prevent hyperlipidemia in our daily life. Therefore, the intake of beneficial food for lowering the risk of hyperlipidemia is needed.

Tomato is a highly consumed vegetable worldwide and has plenty of health benefits. Tomatoes contain a high amount of fiber, oligosaccharides, and polysaccharides which act as prebiotic compounds in the gut environment (Bornet et al., 2002). Tomatoes reduce prostate and breast cancer risk, which might be related to the antioxidant properties of lycopene (Sato et al., 2002; Ilic and Misso, 2012). Lycopene in tomatoes showed the effect on protecting osteoporosis in postmenopausal women (Mackinnon et al., 2011). Nonetheless, there is limited information on the effects of cherry tomatoes (Solanum lycopersicum) on cardiovascular health. The aim of the present study was to evaluate the effects of cherry tomato supplementation (CTS) on reducing the risk of

* Received: November 9, 2017 / Revised: December 12, 2017 / Accepted: December 12, 2017

${ }^{\dagger}$ Corresponding author: Dahyun Hwang. Department of Biomedical Laboratory Science, Hoseo University, 20, Hoseo-ro 79 beon-gil, Baebang-eup, Asan-si, Chungcheongnam-do 31499, Korea.

Tel: +82-41-540-9628, Fax: +82-41-540-9997, e-mail: hdh@hoseo.edu

(C) The Korean Society for Biomedical Laboratory Sciences. All rights reserved.

(C) This is an Open Access article distributed under the terms of the Creative Commons Attribution Non-Commercial License (http://creativecommons.org/licenses/by-nc/3.0/) which permits unrestricted non-commercial use, distribution, and reproduction in any medium, provided the original work is properly cited. 
cardiovascular diseases in rats. Four types of cherry tomato supplementation diets (CTSDs) were prepared to investigate the beneficial effects of CTSDs on preventing cardiovascular disease.

\section{MATERIALS AND METHODS}

\section{Preparation and analysis of tomato samples}

Cherry "Yoyo" tomatoes harvested from Chungcheongnamdo, South Korea were used in this study. Fresh and processed (heat-treated at $80^{\circ} \mathrm{C}$ for $15 \mathrm{~min}$ ) cherry tomato samples were separated into juice and cake after processing with a pulper (AG-5500, Angel Juicer Co., Pusan, Korea). Fresh and heat-treated tomato juices were designated as $\mathrm{J}-1$ and $\mathrm{J}-2$, respectively. The tomato cake was treated with $1 \%$ Viscozyme $^{\circledR}$ L (Novozymes Inc., Copenhagen, Denmark) $(54: 1, \mathrm{v} / \mathrm{v})$ at $50^{\circ} \mathrm{C}$ for $4 \mathrm{~h}$ with shaking at $200 \mathrm{rpm}$, freezedried, and ground using a grinder (1093 Cyclote, Foss Tecator AB, Höganäs, Sweden). Fresh and heat-treated tomato cakes were designated as $\mathrm{C}-1$ and $\mathrm{C}-2$, respectively. The chemical composition of the cherry tomato powder was determined by the standard AOAC method (Cunniff, 1997). Lycopene was extracted from the cherry tomato powder and calculated based on a standard curve generated by a lycopene standard (Sigma, St Louis, MO, USA) (Koh et al., 2010). The chemical compositions of the cherry tomato powder is shown in Table 1.

\section{Animals}

Male Sprague-Dawley rats (6 weeks old) were purchased from KOATECH (Gyeonggi-do, Pyeongtaek, Korea). They were housed and maintained at a constant temperature (24 $\pm 1{ }^{\circ} \mathrm{C}$ ) and humidity (55\%) with $12 \mathrm{~h}$ cycles of light and dark. Rats were fed AIN-93G (TestDiet, St. Louis, MO, USA) for 7 days prior to experiments to allow adaptation, with free access to water. All experimental procedures were approved by the Korea University Institutional Animal Care and Use Committee (Approval No. KUIACUC-2013-151) and performed in accordance with the Guide for the Care and Use of Laboratory Animals (NIH Publication No. 85-23, 1996). Rats $(n=6)$ received pelleted CTSDs, which were prepared by Feedlab (Gyeonggi-do, Guri, Korea) to have the
Table 1. Chemical compositions of cherry tomato sample

\begin{tabular}{lrrrr}
\hline \hline & \multicolumn{1}{c}{ J-1 } & \multicolumn{1}{c}{ J-2 } & \multicolumn{1}{c}{ C-1 } & \multicolumn{1}{c}{ C-2 } \\
\hline Protein (\%) & 11.9 & 12.4 & 15.2 & 17.2 \\
Lipid (\%) & 1.7 & 3.9 & 5.9 & 7.2 \\
Ash (\%) & 8.7 & 9.1 & 3.8 & 3.5 \\
Crude fiber (\%) & 3.7 & 5.3 & 35.5 & 41.2 \\
Lycopene (mg/100 g) & 180.0 & 241.7 & 130.2 & 166.6 \\
\hline
\end{tabular}

same chemical compositions (Table 2). Each CTSD was divided into two groups according to contents (6\% and $12 \%)$ to investigate of concentration-dependent effect. Each CTSD was compensated to contain the same amount of protein (\%), lipid (\%), and crude fiber (\%) using casein (protein), soybean oil (lipid), and cellulose (crude fiber). Corn starch was used to adjust the total amount of carbohydrate.

\section{Measurement of health indices in serum}

The changes in health indices in the serum of rats fed CTSDs for 4 weeks were analyzed. Food intake was measured daily, and body weights were determined weekly. Daily food intake, body weights, food efficiency ratio (FER), and relative liver weight were determined according to the previous reports (Kim et al., 2011; Jo et al., 2014). Serum alanine aminotransferase (AST), aspartate aminotransferase (ALT), glucose, TG, total cholesterol (TC), and HDL-C were measured using the FUSI DRI-CHEM SLIDE kit and a FUSI DRI-CHEM 4000 analyzer (Fujifilm, Tokyo, Japan). The serum LDL-C and very low-density lipoprotein cholesterol (VLDL-C) levels were calculated by applying Friedwann's equation (Jo et al., 2014). The atherogenic index (AI) and the coronary artery risk index (CRI) were calculated according to the previous reports (Abbott et al., 1988; Adeneye et al., 2010).

\section{Measurement of serotonin in serum}

Serum serotonin (5-hydroxytryptamine) levels were measured using an enzyme-linked immunosorbent assay (ELISA; IBL Immuno Biological Lab, Hamburg, Germany) according to the manufacturer's instructions. 
Table 2. Composition of diet for rats used in this study

\begin{tabular}{lrrrrrrrrr}
\hline \hline $\begin{array}{c}\text { Composition } \\
\text { (g/kg diet) }\end{array}$ & $\mathrm{J}-1-6 \%$ & $\mathrm{~J}-1-12 \%$ & $\mathrm{~J}-2-6 \%$ & $\mathrm{~J}-2-12 \%$ & $\mathrm{C}-1-6 \%$ & $\mathrm{C}-1-12 \%$ & $\mathrm{C}-2-6 \%$ & $\mathrm{C}-2-12 \%$ & Control \\
\hline Casein & 192.9 & 185.8 & 192.6 & 185.2 & 190.9 & 181.8 & 189.7 & 179.4 & 200.0 \\
Sucrose & 100.0 & 100.0 & 100.0 & 100.0 & 100.0 & 100.0 & 100.0 & 100.0 & 100.0 \\
Dextrose & 132.0 & 132.0 & 132.0 & 132.0 & 132.0 & 132.0 & 132.0 & 132.0 & 132.0 \\
Corn starch & 347.8 & 298.1 & 350.4 & 303.3 & 371.4 & 345.3 & 376.8 & 356.1 & 397.5 \\
Cellulose & 47.8 & 45.6 & 46.8 & 43.7 & 28.7 & 7.4 & 25.3 & 0.6 & 50.0 \\
Soybean oil & 69.0 & 68.0 & 67.7 & 65.3 & 66.5 & 63.0 & 65.7 & 61.4 & 70.0 \\
J-1 & 60.0 & 120.0 & 0.0 & 0.0 & 0.0 & 0.0 & 0.0 & 0.0 & 0.0 \\
J-2 & 0.0 & 0.0 & 60.0 & 120.0 & 0.0 & 0.0 & 0.0 & 0.0 & 0.0 \\
C-1 & 0.0 & 0.0 & 0.0 & 0.0 & 60.0 & 120.0 & 0.0 & 0.0 & 0.0 \\
C-2 & 0.0 & 0.0 & 0.0 & 0.0 & 0.0 & 0.0 & 60.0 & 120.0 & 0.0 \\
Mineral & 35.0 & 35.0 & 35.0 & 35.0 & 35.0 & 35.0 & 35.0 & 35.0 & 35.0 \\
Vitamin mix & 10.0 & 10.0 & 10.0 & 10.0 & 10.0 & 10.0 & 10.0 & 10.0 & 10.0 \\
L-cystine & 3.0 & 3.0 & 3.0 & 3.0 & 3.0 & 3.0 & 3.0 & 3.0 & 3.0 \\
Choline bitartrate & 2.5 & 2.5 & 2.5 & 2.5 & 2.5 & 2.5 & 2.5 & 2.5 & 2.5 \\
\hline Protein & 203.0 & 203.0 & 203.0 & 203.0 & 203.0 & 203.0 & 203.0 & 203.0 & 203.0 \\
Lipid & 70.0 & 70.0 & 70.0 & 70.0 & 70.0 & 70.0 & 70.0 & 70.0 & 70.0 \\
TDF & 50.0 & 50.0 & 50.0 & 50.0 & 50.0 & 50.0 & 50.0 & 50.0 & 50.0 \\
\hline & & & & & & & &
\end{tabular}

\section{Statistical analysis}

All statistical analyses were performed using SPSS (SPSS, Chicago, IL, USA). The differences among groups were evaluated by analysis of variance (ANOVA), followed by Duncan's multiple range tests. A level of $P<0.05$ was considered statistically significant.

\section{RESULTS AND DISCUSSION}

\section{Chemical compositions analysis of CTSDs}

The chemical compositions of CTSDs are shown in Table 1. To improve of bioavailability of tomatoes, we did two procedures such as heat treatment and enzyme treatment. Heating and fine grinding of foods could increase bioavailability by disrupting or softening the plant cell wall (Hussein and El-Tohamy, 1990). The use of multi-enzymatic complexes, such as Viscozyme-L, which contain cellulases, arabinases, hemicellulases, gluconases, and xylanases, causes the rupture of the cell walls, favoring the extraction of useful compounds (protein and sugars) from the vegetable tissues
(Dueñas et al., 2007). As a result, heat treatment increased protein, lipid, crude fiber and lycopene in both juice and cake samples (Table 1)

\section{Body weight, food intake and relative liver weight}

Rats fed different CTSDs exhibited a significant decrease $(P<0.05)$ in food intake and body weight compared with the control (Table 3). However, the body weight was higher in the $12 \%$ supplemented CTSD than that in the $6 \%$ supplemented CTSD. Although all diets had the same amount of protein, lipid, and fiber, the FERs in all rats fed CTSDs significantly decreased $(P<0.05)$ compared with the control, and the FERs of the juice powder diet groups were higher than those of the cake powder diet groups. The FERs of rats fed different CTSDs were $8 \sim 34 \%$ lower than that of the control, which indicates that CTSDs might be useful for losing weight. Although the body weight and FER decreased in rats fed CTSDs, there were no changes in the relative liver weight. 
Table 3. Body weight, food intake, food efficiency ratio, and relative liver weight in rats fed different CTSDs for 4 weeks

\begin{tabular}{lcccc}
\hline \hline Group & $\begin{array}{c}\text { Body weight } \\
(\mathrm{g} / \text { day })\end{array}$ & $\begin{array}{c}\text { Food intake } \\
(\mathrm{g} / \text { day })\end{array}$ & $\begin{array}{c}\text { FER } \\
(\%)\end{array}$ & $\begin{array}{c}\text { Relative liver weight } \\
(\mathrm{g} / 100 \mathrm{~g} \text { body weight })\end{array}$ \\
\hline $\mathrm{J} 1-6 \%$ & $3.31 \pm 0.16^{\mathrm{ab}}$ & $15.92 \pm 0.11^{\mathrm{ab}}$ & $0.21 \pm 0.00^{\mathrm{a}}(72.12)$ & $2.93 \pm 0.45^{\mathrm{a}}$ \\
$\mathrm{J} 1-12 \%$ & $3.48 \pm 0.11^{\mathrm{bc}}$ & $15.25 \pm 0.42^{\mathrm{a}}$ & $0.23 \pm 0.01^{\mathrm{ab}}(79.12)$ & $2.98 \pm 0.09^{\mathrm{a}}$ \\
$\mathrm{J} 2-6 \%$ & $3.76 \pm 0.19^{\mathrm{c}}$ & $15.57 \pm 0.06^{\mathrm{ab}}$ & $0.24 \pm 0.00^{\mathrm{bc}}(83.75)$ & $3.12 \pm 0.17^{\mathrm{a}}$ \\
$\mathrm{J} 2-12 \%$ & $4.17 \pm 0.29^{\mathrm{d}}$ & $15.88 \pm 0.79^{\mathrm{ab}}$ & $0.26 \pm 0.01^{\mathrm{cd}}(91.24)$ & $3.08 \pm 0.16^{\mathrm{a}}$ \\
$\mathrm{C} 1-6 \%$ & $3.09 \pm 0.15^{\mathrm{a}}$ & $14.74 \pm 0.96^{\mathrm{a}}$ & $0.21 \pm 0.01^{\mathrm{a}}(72.80)$ & $3.02 \pm 0.32^{\mathrm{a}}$ \\
$\mathrm{C} 1-12 \%$ & $3.10 \pm 0.06^{\mathrm{a}}$ & $14.79 \pm 0.47^{\mathrm{a}}$ & $0.21 \pm 0.01^{\mathrm{a}}(72.67)$ & $2.97 \pm 0.20^{\mathrm{a}}$ \\
$\mathrm{C} 2-6 \%$ & $3.63 \pm 0.23^{\mathrm{bc}}$ & $15.16 \pm 0.95^{\mathrm{a}}$ & $0.24 \pm 0.01^{\mathrm{bc}}(83.23)$ & $3.02 \pm 0.22^{\mathrm{a}}$ \\
$\mathrm{C} 2-12 \%$ & $3.61 \pm 0.06^{\mathrm{bc}}$ & $15.11 \pm 0.55^{\mathrm{a}}$ & $0.24 \pm 0.01^{\mathrm{bc}}(83.05)$ & $2.86 \pm 0.28^{\mathrm{a}}$ \\
$\mathrm{Control}$ & $4.99 \pm 0.22^{\mathrm{e}}$ & $17.38 \pm 1.51^{\mathrm{b}}$ & $0.29 \pm 0.02^{\mathrm{d}}(100.00)$ & $2.92 \pm 0.07^{\mathrm{a}}$ \\
\hline
\end{tabular}

The control diet consisted of AIN-93G. Values were expressed as a mean \pm SD of three independent experiments. The FERs of the samples were normalized by taking the FER of the control to be $100 \%$ and are shown in parentheses.

abcde Values in the same column not sharing a common superscript are significantly different $(P<0.05)$ from each other.

Table 4. Serum analysis of collected blood of rats fed different CTSDs for 4 weeks

\begin{tabular}{|c|c|c|c|c|c|c|c|c|c|c|}
\hline Group & $\begin{array}{l}\text { AST } \\
(\mathrm{U} / \mathrm{L}) \\
\end{array}$ & $\begin{array}{l}\text { ALT } \\
(\mathrm{U} / \mathrm{L})\end{array}$ & $\begin{array}{c}\text { Glucose } \\
(\mathrm{U} / \mathrm{L})\end{array}$ & $\begin{array}{c}\text { TG } \\
(\mathrm{U} / \mathrm{L})\end{array}$ & $\begin{array}{c}\mathrm{TC} \\
(\mathrm{mg} / \mathrm{dL})\end{array}$ & $\begin{array}{l}\text { LDL-C } \\
(\mathrm{mg} / \mathrm{dL})\end{array}$ & $\begin{array}{l}\text { HDL-C } \\
(\mathrm{mg} / \mathrm{dL})\end{array}$ & $\begin{array}{l}\text { VLDL-C } \\
(\mathrm{mg} / \mathrm{dL})\end{array}$ & $\mathrm{AI}$ & CRI \\
\hline J1-6\% & $\begin{array}{c}87.00 \pm \\
5.66^{\mathrm{a}}\end{array}$ & $\begin{array}{c}26.50 \pm \\
0.71^{\mathrm{ab}}\end{array}$ & $\begin{array}{c}116.33 \pm \\
10.97^{\mathrm{a}}\end{array}$ & $\begin{array}{r}45.00 \pm \\
3.61^{\mathrm{abc}}\end{array}$ & $\begin{array}{c}57.33 \pm \\
4.04^{\mathrm{a}}\end{array}$ & $\begin{array}{c}9.13 \pm \\
1.70^{\mathrm{a}}\end{array}$ & $\begin{array}{c}44.00 \pm \\
1.00^{\mathrm{a}}\end{array}$ & $\begin{array}{c}10.13 \pm \\
0.76^{\mathrm{a}}\end{array}$ & $\begin{array}{l}0.21 \pm \\
0.05^{\mathrm{ab}}\end{array}$ & $\begin{array}{c}1.30 \pm \\
0.06^{\mathrm{b}}\end{array}$ \\
\hline $\mathrm{J} 1-12 \%$ & $\begin{array}{c}83.00 \pm \\
4.24^{\mathrm{a}}\end{array}$ & $\begin{array}{c}33.00 \pm \\
4.24^{\mathrm{b}}\end{array}$ & $\begin{array}{c}102.33 \pm \\
5.69^{\mathrm{ab}}\end{array}$ & $\begin{array}{c}37.33 \pm \\
6.11^{\mathrm{ab}}\end{array}$ & $\begin{array}{c}59.00 \pm \\
7.94^{\mathrm{a}}\end{array}$ & $\begin{array}{c}10.87 \pm \\
0.83^{\mathrm{ab}}\end{array}$ & $\begin{array}{c}47.33 \pm \\
1.15^{\mathrm{ab}}\end{array}$ & $\begin{array}{c}9.80 \pm \\
0.87^{\mathrm{a}}\end{array}$ & $\begin{array}{c}0.23 \pm \\
0.03^{\mathrm{ab}}\end{array}$ & $\begin{array}{c}1.25 \pm \\
0.02^{\mathrm{a}}\end{array}$ \\
\hline J2-6\% & $\begin{array}{c}91.00 \pm \\
1.41^{\mathrm{a}}\end{array}$ & $\begin{array}{c}26.50 \pm \\
0.71^{\mathrm{ab}}\end{array}$ & $\begin{array}{c}110.33 \pm \\
8.50^{\mathrm{a}}\end{array}$ & $\begin{array}{c}67.67 \\
17.62^{ \pm}\end{array}$ & $\begin{array}{c}71.33 \pm \\
4.04^{\mathrm{b}}\end{array}$ & $\begin{array}{c}11.00 \pm \\
2.12^{\mathrm{ab}}\end{array}$ & $\begin{array}{l}49.33 \pm \\
2.52^{\mathrm{abc}}\end{array}$ & $\begin{array}{c}21.20 \pm \\
1.60^{\mathrm{b}}\end{array}$ & $\begin{array}{l}0.22 \pm \\
0.02^{\mathrm{ab}}\end{array}$ & $\begin{array}{l}1.45 \pm \\
0.04^{\mathrm{c}}\end{array}$ \\
\hline $\mathrm{J} 2-12 \%$ & $\begin{array}{c}82.50 \pm \\
9.19^{\mathrm{a}}\end{array}$ & $\begin{array}{c}24.00 \pm \\
5.66^{\mathrm{a}}\end{array}$ & $\begin{array}{c}92.33 \pm \\
9.29^{\mathrm{b}}\end{array}$ & $\begin{array}{c}56.33^{ \pm} \\
10.79^{\mathrm{cd}}\end{array}$ & $\begin{array}{c}68.67 \pm \\
8.08^{\mathrm{ab}}\end{array}$ & $\begin{array}{c}14.40 \pm \\
2.78^{\mathrm{bc}}\end{array}$ & $\begin{array}{c}55.67 \pm \\
0.58^{\mathrm{d}}\end{array}$ & $\begin{array}{c}15.13 \pm \\
2.52^{\mathrm{c}}\end{array}$ & $\begin{array}{c}0.26 \pm \\
0.04^{\mathrm{ab}}\end{array}$ & $\begin{array}{c}1.23 \pm \\
0.07^{\mathrm{a}}\end{array}$ \\
\hline C1-6\% & $\begin{array}{c}82.50 \pm \\
6.36^{\mathrm{a}}\end{array}$ & $\begin{array}{c}22.00 \pm \\
5.66^{\mathrm{a}}\end{array}$ & $\begin{array}{c}103.33 \pm \\
2.08^{\mathrm{ab}}\end{array}$ & $\begin{array}{c}35.00 \pm \\
6.93^{\mathrm{b}}\end{array}$ & $\begin{array}{c}60.00 \pm \\
1.73^{\mathrm{ab}}\end{array}$ & $\begin{array}{c}11.13 \pm \\
2.20^{\mathrm{ab}}\end{array}$ & $\begin{array}{c}46.67 \pm \\
2.52^{\mathrm{ab}}\end{array}$ & $\begin{array}{c}8.87 \pm \\
1.36^{\mathrm{a}}\end{array}$ & $\begin{array}{l}0.24 \pm \\
0.03^{\mathrm{ab}}\end{array}$ & $\begin{array}{l}1.29 \pm \\
0.05^{\mathrm{ab}}\end{array}$ \\
\hline C1-12\% & $\begin{array}{c}88.50 \pm \\
2.12^{\mathrm{a}}\end{array}$ & $\begin{array}{c}29.50 \pm \\
4.95^{\mathrm{ab}}\end{array}$ & $\begin{array}{c}102.00 \pm \\
8.19^{\mathrm{ab}}\end{array}$ & $\begin{array}{c}32.67 \pm \\
3.79^{\mathrm{b}}\end{array}$ & $\begin{array}{c}64.00 \pm \\
7.94^{\mathrm{ab}}\end{array}$ & $\begin{array}{c}15.87^{ \pm} \pm \\
4.24^{\mathrm{c}}\end{array}$ & $\begin{array}{c}47.67 \pm \\
4.51^{\mathrm{ab}}\end{array}$ & $\begin{array}{l}8.93 \pm \\
1.42^{\mathrm{a}}\end{array}$ & $\begin{array}{c}0.33 \pm \\
0.06^{\mathrm{c}}\end{array}$ & $\begin{array}{c}1.34 \underset{ \pm}{ \pm} \\
0.02^{\mathrm{b}}\end{array}$ \\
\hline $\mathrm{C} 2-6 \%$ & $\begin{array}{c}78.00 \pm \\
7.07^{\mathrm{a}}\end{array}$ & $\begin{array}{c}21.00 \pm \\
1.41^{\mathrm{a}}\end{array}$ & $\begin{array}{c}93.67 \pm \\
3.79^{\mathrm{b}}\end{array}$ & $\begin{array}{c}31.33 \pm \\
8.08^{\mathrm{b}}\end{array}$ & $\begin{array}{c}67.67 \pm \\
8.02^{\mathrm{ab}}\end{array}$ & $\begin{array}{c}14.27 \pm \\
1.97^{\mathrm{bc}}\end{array}$ & $\begin{array}{c}54.00 \pm \\
4.00^{\mathrm{cd}}\end{array}$ & $\begin{array}{c}8.47 \pm \\
0.50^{\mathrm{a}}\end{array}$ & $\begin{array}{c}0.26 \pm \\
0.05^{\mathrm{ab}}\end{array}$ & $\begin{array}{c}1.25 \pm \\
0.02^{\mathrm{a}}\end{array}$ \\
\hline $\mathrm{C} 2-12 \%$ & $\begin{array}{c}81.00 \pm \\
7.07^{\mathrm{a}}\end{array}$ & $\begin{array}{c}27.50 \pm \\
0.71^{\mathrm{ab}}\end{array}$ & $\begin{array}{c}104.33 \\
4.04^{\mathrm{ab}}\end{array}$ & $\begin{array}{c}29.00 \pm \\
5.57^{\mathrm{b}}\end{array}$ & $\begin{array}{c}63.00 \pm \\
5.29^{\mathrm{ab}}\end{array}$ & $\begin{array}{c}18.13 \pm \\
2.01^{\mathrm{c}}\end{array}$ & $\begin{array}{l}51.33 \pm \\
3.79^{\text {bcd }}\end{array}$ & $\begin{array}{c}8.67 \pm \\
1.67^{\mathrm{a}}\end{array}$ & $\begin{array}{c}0.35 \pm \\
0.02^{\mathrm{c}}\end{array}$ & $\begin{array}{c}1.23 \pm \\
0.07^{\mathrm{a}}\end{array}$ \\
\hline Control & $\begin{array}{c}92.50 \pm \\
9.19^{\mathrm{a}}\end{array}$ & $\begin{array}{c}24.50 \pm \\
0.71^{\mathrm{ab}}\end{array}$ & $\begin{array}{c}116.00 \pm \\
9.17^{\mathrm{a}}\end{array}$ & $\begin{array}{c}51.33 \pm \\
3.51^{\mathrm{ac}}\end{array}$ & $\begin{array}{c}61.00 \pm \\
4.58^{\mathrm{ab}}\end{array}$ & $\begin{array}{c}14.27 \pm \\
2.64^{\mathrm{bc}}\end{array}$ & $\begin{array}{c}38.00 \pm \\
4.00^{\mathrm{e}}\end{array}$ & $\begin{array}{c}13.07 \pm \\
2.90^{\mathrm{c}}\end{array}$ & $\begin{array}{c}0.38 \pm \\
0.13^{\mathrm{cd}}\end{array}$ & $\begin{array}{c}1.61 \pm \\
0.09^{d}\end{array}$ \\
\hline
\end{tabular}

Values were expressed as a mean \pm SD of three independent experiments.

${ }^{\text {abcde }}$ Values in the same column not sharing a common superscript are significantly different $(P<0.05)$ from each other.

\section{Serum analysis}

At the end of the 4-week experiment, AST and ALT values in rats fed CTSDs were not significantly different from those in the control, indicating the absence of hepatotoxicity (Table 4). The glucose levels were significantly reduced $(P<0.05)$, except in the $6 \%$-J-1 group, and the reduction was more significant in the high CTSD group than in the low CTSD group, except in the C-2 group. The TG levels were significantly reduced $(P<0.05)$, except in the J-2 group. Different CTSDs significantly increased $(P$ $<0.05)$ the HDL-C level compared with the control. The 
Table 5. Serum serotonin concentration of rats fed different CTSDs for 4 weeks

\begin{tabular}{lc}
\hline \hline Group & Serotonin $(\mathrm{ng} / \mathrm{mL})$ \\
\hline $\mathrm{J}-1-6 \%$ & $3.50 \pm 0.03^{\mathrm{ab}}$ \\
$\mathrm{J}-1-12 \%$ & $3.55 \pm 0.02^{\mathrm{ab}}$ \\
$\mathrm{J}-2-6 \%$ & $3.50 \pm 0.08^{\mathrm{ab}}$ \\
$\mathrm{J}-2-12 \%$ & $3.51 \pm 0.01^{\mathrm{ab}}$ \\
$\mathrm{C}-1-6 \%$ & $3.47 \pm 0.01^{\mathrm{ad}}$ \\
$\mathrm{C}-1-12 \%$ & $3.50 \pm 0.04^{\mathrm{ab}}$ \\
$\mathrm{C}-2-6 \%$ & $3.52 \pm 0.02^{\mathrm{ab}}$ \\
$\mathrm{C}-2-12 \%$ & $3.30 \pm 0.01^{\mathrm{c}}$ \\
Control & $3.42 \pm 0.04^{\mathrm{d}}$ \\
\hline
\end{tabular}

Values were expressed as a mean \pm SD of three independent experiments.

${ }^{\text {abcd }}$ Values in the same column not sharing a common superscript are significantly different $(P<0.05)$ from each other.

HDL-C level was higher in rats fed the $12 \%$ supplemented diet than those fed the $6 \%$ supplemented diet. In the $12 \%-\mathrm{J}-2$ group, the HDL increased 1.47-fold compared with the control. However, there was no significant effect of CTSD on the reduction of TC and LDL-C. Treatment of CTDSs significantly $(P<0.05)$ decreased the $\mathrm{AI}$ and $\mathrm{CRI}$ compared with the control, and the AI and CRI were 1.1- to 1.8-fold and 1.1- to 1.3-fold reduction, respectively. Tomato supplementation decreased serum lipids (TC, LDL-C, and TG) levels in rats fed a high cholesterol diet (Nouri and Abad, 2013); however, in the present study, TC level was not lowered in the rats fed CTDS compared with the control. The $\mathrm{AI}$ and $\mathrm{CRI}$ are predicators of cardiovascular risk, which means that an elevation of $\mathrm{AI}$ and CRI indicates an increase in cardiovascular risk. A high level of cardiovascular risk results in atherosclerosis and coronary artery disease (Hokanson and Austin, 1996; Fki et al., 2005). A high AI and CRI correlate with low HDL-C and high TC levels or the LDL-C level and vice versa. In the present study, although the HDL-C level in CTSD-fed rats increased significantly, there was no significant reduction in the TC and LDL-C levels in CTSD-fed rats. Therefore, the significant reduction of AI and CRI in the rats fed CTDS was mainly caused not by a decrease in the levels of TC, LDL-C, and VLDL-C but by a significant increase in the HDL-C level.
To explain changes in eating behavior, meal size, and body weight by feeding CTSD, the serum serotonin level was measured. Serum serotonin levels significantly increased $(P<0.05)$ in a dose-dependent manner in rats fed different CTSDs, except in the C-2 group (Table 5). Diet influences the serotonergic system, and horses fed a high fiber diet show significantly higher serotonin levels than those fed a high starch diet (Alberghina et al., 2010). Serotonin plays an important role in feeding and appetite control, and a lack of serotonin can increase food intake (Tecott et al., 1995; Leibowitz and Alexander, 1998). In this study, CTSDs increased serotonin, which might affect the reduction of food intake and body weight gain.

In conclusion, CTSD feeding lowered FER, and significantly increased HDL-C, resulted in AI and CRI reduction. In addition, CTSD increased serum serotonin level. Therefore, a constant intake of cherry tomato might reduce the potential risk of cardiovascular disease in healthy individuals as well as in individuals with hyperlipidemia.

\section{ACKNOWLEDGEMENTS}

None.

\section{CONFLICT OF INTEREST}

The authors have no conflicts of interest to disclose.

\section{REFERENCES}

Abbott RD, Wilson PW, Kannel WB, Castelli WP. High density lipoprotein cholesterol, total cholesterol screening, and myocardial infarction. The Framingham study. Arteriosclerosis, Thrombosis, and Vascular Biology. 1988. 8: 207-211.

Adeneye AA, Adeyemi OO, Agbaje EO. Anti-obesity and antihyperlipidaemic effect of hunteria umbellata seed extract in experimental hyperlipidaemia. Journal of Ethnopharmacology. 2010. 130: 307-314.

Alberghina D, Giannetto C, Visser E, Ellis A. Effect of diet on plasma tryptophan and serotonin in trained mares and geldings. Veterinary Record. 2010. 166: 133-136.

Barter P. The role of HDL-cholesterol in preventing atherosclerotic disease. European Heart Journal Supplements. 2005. 7: F4-F8.

Berrougui H, Momo CN, Khalil A. Health benefits of high-density lipoproteins in preventing cardiovascular diseases. Journal of 
Clinical Lipidology. 2012. 6: 524-533.

Bornet F, Brouns F, Tashiro Y, Duvillier V. Nutritional aspects of short-chain fructooligosaccharides: natural occurrence, chemistry, physiology and health implications. Digestive and Liver Disease. 2002. 34: S111-S120.

Cunniff P. AOAC international: Gaithersburg. 1997.

Dueñas M, Hernández T, Estrella I. Changes in the content of bioactive polyphenolic compounds of lentils by the action of exogenous enzymes. Effect on their antioxidant activity. Food Chemistry. 2007. 101: 90-97.

Fki I, Bouaziz M, Sahnoun Z, Sayadi S. Hypocholesterolemic effects of phenolic-rich extracts of chemlali olive cultivar in rats fed a cholesterol-rich diet. Bioorganic and Medicinal Chemistry. 2005. 13: 5362-5370.

Hokanson JE, Austin MA. Plasma triglyceride level is a risk factor for cardiovascular disease independent of high-density lipoprotein cholesterol level: A metaanalysis of population-based prospective studies. Journal of Cardiovascular Risk. 1996. 3 : 213-219.

Hussein L, El-Tohamy M. Vitamin a potency of carrot and spinach carotenes in human metabolic studies. International journal for vitamin and nutrition research. Internationale Zeitschrift fur Vitamin-und Ernahrungsforschung. Journal International De Vitaminologie Et De Nutrition. 1990. 60: 229-235.

Ilic D, Misso M. Lycopene for the prevention and treatment of benign prostatic hyperplasia and prostate cancer: A systematic review. Maturitas. 2012. 72: 269-276.

Jo SP, Kim JK, Lim YH. Antihyperlipidemic effects of stilbenoids isolated from morus alba in rats fed a high-cholesterol diet. Food and Chemical Toxicology. 2014. 65: 213-218.

Kim KY, Park CW, Kim HM, Kang IC, Jeong HJ. Effects of acanthopanax divaricatus var. Albeofructus in mice submitted to protein restriction. Oriental Pharmacy and Experimental Medicine. 2011. 11: 15-23.

Koh JH, Kim Y, Oh JH. Chemical characterization of tomato juice fermented with bifidobacteria. Journal of Food Science. 2010. 75: 428-432.

Leibowitz SF, Alexander JT. Hypothalamic serotonin in control of eating behavior, meal size, and body weight. Biological Psychiatry. 1998. 44: 851-864.

Mackinnon E, Rao A, Josse R, Rao L. Supplementation with the antioxidant lycopene significantly decreases oxidative stress parameters and the bone resorption marker n-telopeptide of type i collagen in postmenopausal women. Osteoporosis International. 2011. 22: 1091-1101.

Nouri MHK, Abad ANA. Comparative study of tomato and tomato paste supplementation on the level of serum lipids and lipoproteins levels in rats fed with high cholesterol. Iranian Red Crescent Medical Journal. 2013. 15: 287.

Sato R, Helzlsouer KJ, Alberg AJ, Hoffman SC, Norkus EP, Comstock GW. Prospective study of carotenoids, tocopherols, and retinoid concentrations and the risk of breast cancer. Cancer Epidemiology and Prevention Biomarkers. 2002. 11: 451-457.

Tecott LH, Sun LM, Akana SF, Strack AM, Lowenstein DH, Dallman MF, Julius D. Eating disorder and epilepsy in mice lacking 5-ht2c serotonin receptors. Nature. 1995. 374: 542 -546 .

https://doi.org/10.15616/BSL.2017.23.4.321

Cite this article as: JH Koh, YH Lim, D Hwang. Cherry Tomato Supplementation Reduces Cardiovascular Risk. Biomedical Science Letters. 2017. 23: 321-326. 